\title{
The Internal Courtyard's DAYLIGHTING for the Environmental Architecture of MASJID in Cairo
}

Dr. Ahmed Fekry - Dr. Ihab Elshazly - Eng. Ahmed Almrazky

\begin{abstract}
Internal courtyard played a vital role in the architecture of many civilizations in various countries, centuries and building's kinds. It was a major element in the architecture of MASJID in a variety of natural environmental conditions for nearly thousand years, then gradually disappeared nowadays. So the aim of this theoretical and practical study, is to present the importance of the internal courtyard's DAYLIGHTING for the environmental architecture of MASJID in the city of Cairo, to raise the values of DAYLIGHTING's factor and intensity, with the quality of its distribution inside the space around the day, in addition to its role in meeting the human needs of ventilation, thermal comfort, de-noising, availability of sky and hosting various religious, cultural and social activities, which support the ecosystem. On the other hand, clerestory, dome, exterior windows, and artificial lighting do not meet the functional needs, and they increase energy consumption, in addition to their psychological and social negative impacts, which increase the pollution loads on the environment. So we have to support the internal courtyard in architecture, using suitable technology to take advantages of DAYLIGHTING and the natural resources for supporting the ecosystem. ${ }^{1}$
\end{abstract}

Keywords: Courtyard, DAYLIGHT, Environment, Architecture, MASJID, Energy.

\section{Introduction}

The purpose of man's creation is the worship of Almighty God, and one of this worship's means is developing the universe, in the built and natural environment, according to integrated mutual relation. MASJID as a house of worship is one of the most important architectural requirements for a person, so KAABA is the first house established for the people in MAKKA. and planning MASJID was the first actions taken by the Prophet MOHAMMAD after his emigration and arrival to MEDINA ${ }^{2}$.

Fig (1) Courtyard around KAABA. ${ }^{3}$

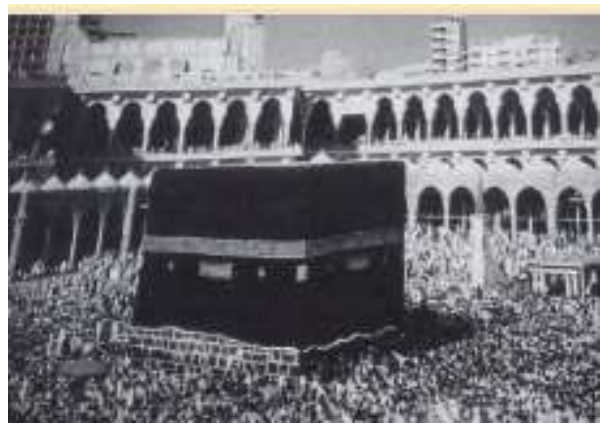

Fig (2) Early courtyard inside Prophet's MASJID. ${ }^{4}$

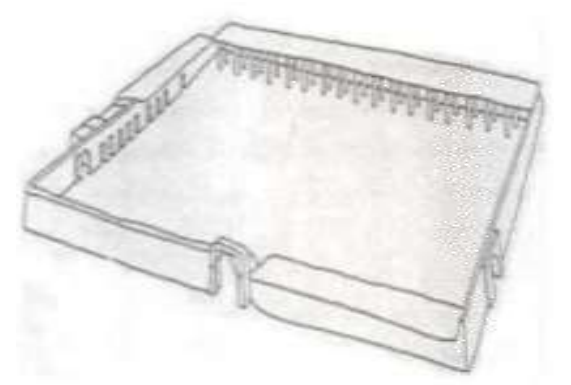

The courtyard is an important architectural element, since it has been associated with MASJID at various time and place (around KAABA or inside Prophet's MASJID and in other

\footnotetext{
${ }^{1}$ Ahmed Almrazky, 2010.

${ }^{2}$ Brenister Fletcher, 1996.

${ }^{3}$ Ira G. Zepp, 2000.

${ }^{4}$ Syed I. Ariffin, 2005.
} 
MASJIDs in many different countries for centuries). It provided a suitable space that accommodate growing numbers of worshipers, doing various activities like holding councils of science, judiciary, nursing and entertainment... etc, till it gradually disappeared from the contemporary architecture of MASJID, in a phenomenon calls into question.

\section{Problem}

Some of the countries facing the harsh climatic conditions divided MASJID to prayer's hall and covered internal courtyard to protect it from heavy rain and stinging cold. This trend was Then spread in the rest of the countries, even Cairo city, without taking into account the importance of the different environmental conditions effect from a region to another. Then MASIID became covered by clerestory and dome, till the inner courtyard disappeared gradually from the architecture of MASJID causing the following:

Fig (3) MASJID SULTAN QAYTBAY covered by Clerestory $^{5}$



Fig (4) MASJID SULAYMAN PASHA covered by Dome $^{6}$

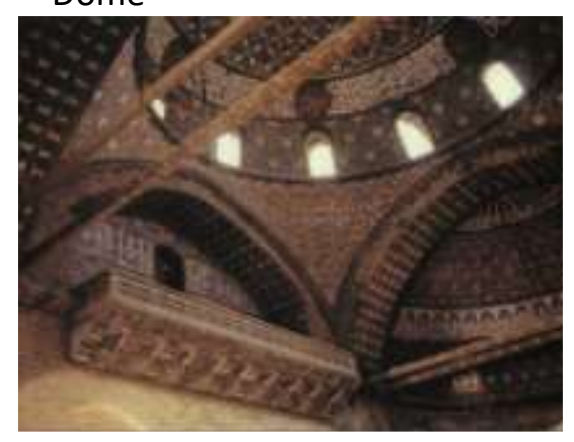

- Openness to the outside world and increased areas of external windows to address the imbalance in poor lighting and ventilation distribution inside MASJID, due to the lack of the inner courtyard leads to suffering from external noise damage and deterioration of thermal comfort.

- Avoid outside disadvantages by reducing windows areas leads to suffering from darkness, poor lighting and bad distribution of ventilation.

- The use of artificial systems of bulbs, fans, air-conditioners, to provide lighting, ventilation and thermal comfort of MASJID, leads to raise the consumption of different sources of energy like oil, diesel fuel and electricity.

- Difficulty of doing various activities in a closed space of MASJID because of the interference and inconvenience to each other, leads to increase needs to specialized buildings for these activities independently from MASJID such as schools, libraries, courts, hospitals, clubs ... etc.

\section{Objectives}

To clarify the role of the internal courtyard to provide DAYLIGHTING for the Environmental architecture of MASJID through:

5 Doris Behrens-Abouseif, 1989.

6 Caroline Williams, 2008. 
- The importance of the internal courtyard's DAYLIGHTING of MASJID.

- The environmental impact for the internal courtyard of MASJID.

- Thinking of development possibilities of the internal courtyard of MASJID.

\section{Importance}

The study addressed the internal courtyard's DAYLIGHTING for the environmental architecture of MASJID because of:

- The importance of achieving the humanitarian requirements of DAYLIGHTING and other natural ecosystems for supporting lifecycle system.

- The importance of worship activities diversity in human life.

- The importance of MASJID in accommodating diverse worship activities.

So the study worked to present the role of the internal courtyard's DAYLIGHTING to achieve the maximum possible benefits, provide a practical means by which to assess the DAYLIGHTING ${ }^{7}$ because of its impact on human health, the quality of construction and safety of the environment, and provide statement of how it is needed and the damage resulting from its lack through:

- Diversity of MASJID cases studied in terms of area, design and style.

- The impact of the presence of the internal courtyard against the clerestory and dome coverage.

\section{Methodology}

- Theoretical framework contains display of main concepts underlying the studying accordance with scientific and cultural variety of backgrounds, and the historical evolution of the correlation between courtyard and architecture till the internal courtyard of MASJID in Cairo, and the most important results of previous studies concerned with the elements of this research.

- Practical framework contains the collection and monitoring of lighting, climatic data, and field measurements including lighting intensity, noise levels, temperature, relative humidity, and the inventory of technical equipment in the cases studied of MASJID, and a psychological and social questionnaire, and analysis of all previous data using computer programs. ${ }^{8}$

\subsection{Main Concepts}

Noticing multiplicity of the main concepts and terminologies of the study, led to take advantage of this variety to achieve a possible integration among themselves, to reach the nearest perception of real meaning and right understanding as follows:

- DAYLIGHT' ${ }^{9}$ is a critically important component of the immense flux of short wave photonic energy that flows continuously onto the surface of our Earth from our Sun.

- Courtyard ${ }^{10}$ is an uncovered space inside or outside the building, while the atrium is the covered or uncovered interior space which building's elements meet around.

7 Bangali Jayashri, Shaligram Arvind, 2013.

8 R. G. Bhavani and M. A. Khan, 2011.

${ }^{9}$ Richard Kittler, Miroslav Kocifaj, Stanislav Darula, 2012.

${ }^{10}$ Par Roger Garaudy, 1985. 
Fig (5) Courtyard in MASJID of IBN TULUN. ${ }^{11}$

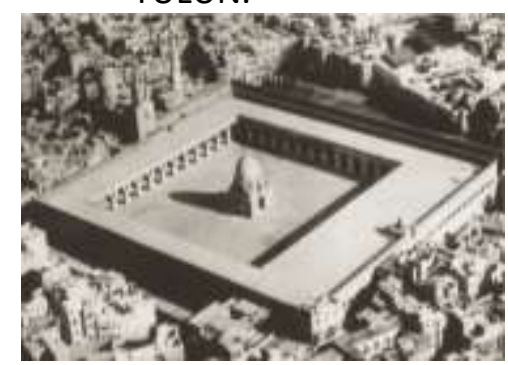

Fig (6) Covering the atrium of MASJID with dome. $^{12}$

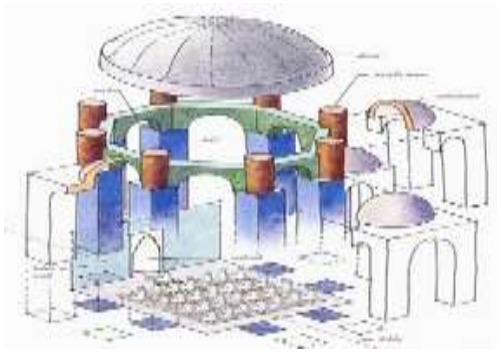

- Environment ${ }^{13}$ is a balanced system around us materially, morally and physically such as land, water, air, biotic like humans, animals, plants, and balanced relations between them.

- Architecture ${ }^{14}$ is providing physical and moral framework that meets human needs supporting life ecosystem.

- MASJID ${ }^{15}$ as a place characterized by holiness, is a house of worship to get closer to God (ALLAH) and where that kneeling (SOJOD) of prayer is as close as possible from God (ALLAH), it is called the name of MASJID.

\subsection{Historical Evolution}

- Availability of sky in architecture is one of Human interests throughout centuries in different cultures and religions ${ }^{16}$.

- So the courtyard was a key element in the architecture of successive civilizations especially religious in different eras and countries.

Fig (7) The relation of internal courtyard to the houses of worship in different cultures.



11 Titus Burckhardt, 2009.

${ }^{12}$ David Macaulay, 2008.

13 J.L. chapman \& M.J. Reiss, 1995.

${ }^{14}$ YEHIA ABDALLAH, 2013.

${ }^{15}$ Robert Hillenbrand, 1994.

${ }^{16}$ Karen Farrington, 2002. 
- The courtyard was linked to MASJID closely, playing a vital role in meeting the physical needs for providing a place to accommodate the congregation, natural lighting, ventilation, thermal comfort and distracting noise. Also in meeting the morals needs for contacting sky visually, providing privacy and tranquility that are commensurate with humility required to the houses of worship.

Fig (8) The relation of internal courtyard to MASJID in different countries and centuries.
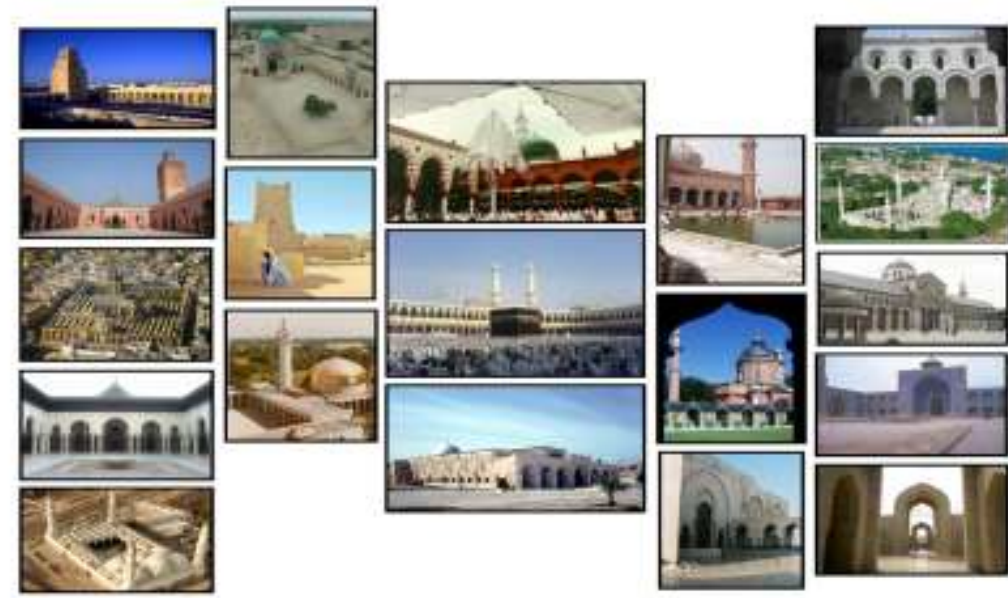

Fig (9) The relation of internal courtyard to Egyptian architecture specially religious.

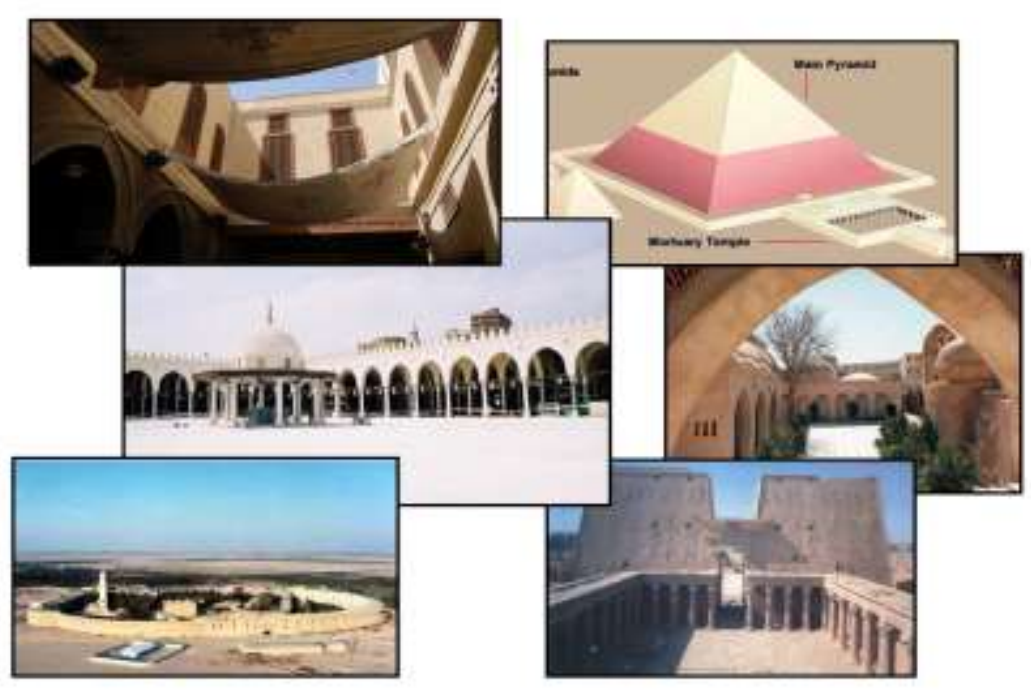

Fig (10) The relation of internal courtyard to MASJID in Cairo city. 



SULTAN HASAN

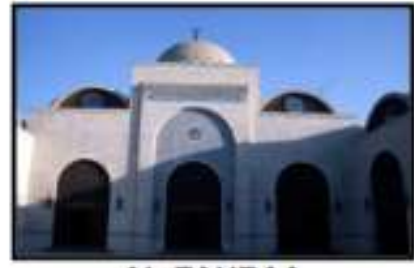

AL-ZAHRAA

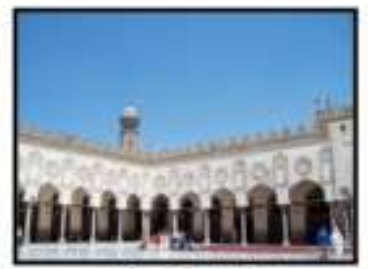

AL-AZHAR

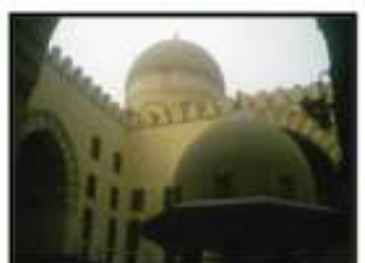

SURGHATMASH

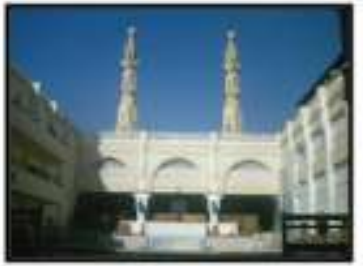

AL-SEDDIK

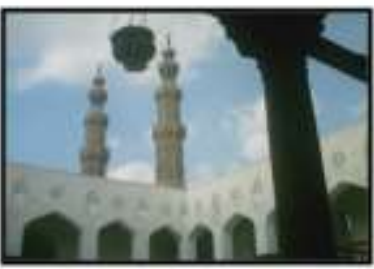

SALEH TALAEA

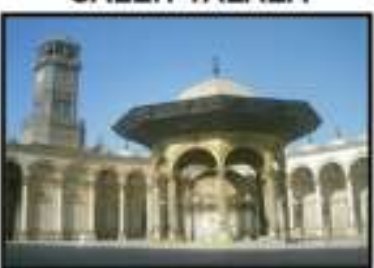

MOHAMED ALI

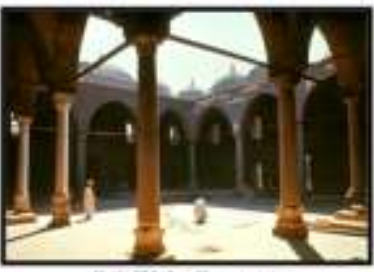

SAFIA Queen

Fig (11) MASJID atrium covered by dome and clerestory in Cairo city.

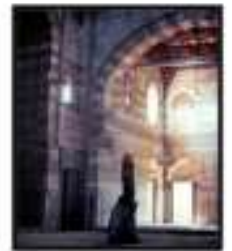

ABO HREBA

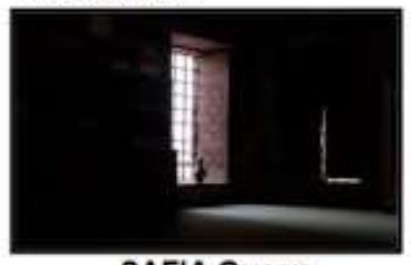

SAFIA Queen

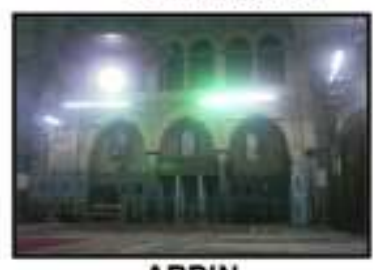

ABDIN



ABO HREBA

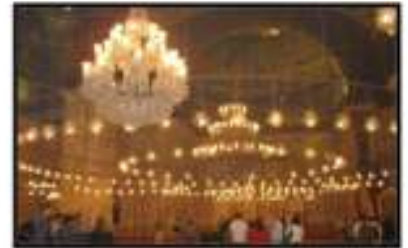

MOHAMED ALI

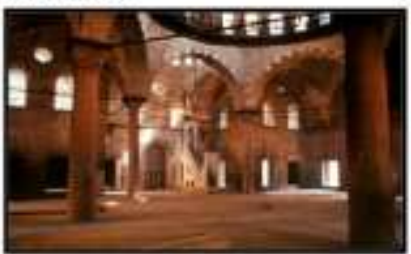

SAFIA Queen

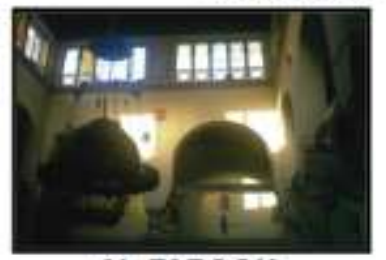

AL-FAROOK

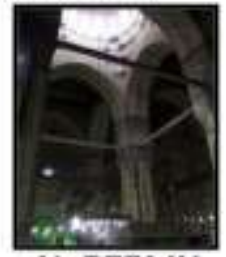

AL-REFAAY



SALAH DEEN

\subsection{Previous Studies}

Noted that few studies were about the design of worship's buildings especially the environmental performance ${ }^{17}$, generally those studies can be classified in groups:

- A group is interested in the architectural design of worship's buildings especially MASJID in terms of functional relationships, manifestations aesthetic, design criteria,

${ }^{17}$ Yasmine Amr Mostafa, 2013. 
planning of MASJID, and the evolution of its architecture design according to the different spatial and temporal conditions.

- A group is interested in architectural Spaces especially courtyards in terms of its relationship with the activity of building, its importance in architecture, studying its evolution over centuries, many civilizations and design criteria.

- A group interested in the Environmental systems in terms of ventilation, thermal comfort and lighting. As this study addressing the impact of the courtyard by analytical and practical studies, monitoring and documenting qualitative and quantitative internal environmental systems of MASJID.

\subsection{Practical Study}

We studied groups of MASJIDs that vary in size and layout and style, some of them have an internal courtyard ( IBN TOLON, AL-SALEH TALAE, SULTAN HASAN, SARGHATMASH, MOHAMED ALI, SAFIA Queen, AL-ZAHRAA, AL-SEDDIK ) while some are covered by clerestory or dome ( ABO HREBA, AL-REFAAY, ABDIN, AL-FAROOK, SALAH DEEN ) to learn DAYLIGHT and environmental performance with and without the internal courtyard through data and updated information according to the following:

- Collecting and monitoring and analyzing the climatic data from Cairo city, by climatic architectural design, which encouraged the compacted urban pattern, based on internal courtyards in buildings and minimizing the external openings.

- Collecting, monitoring and analyzing the geometrical and physical data in MASJID, using measuring devices to monitor the daylight intensity, temperature, relative humidity, and the intensity of noise throughout summer and winter from 9.00 am to $6.00 \mathrm{pm}$ every 3 hours to suit the time of pray at a height of $0.50 \mathrm{~cm}$ and $1.50 \mathrm{~cm}$ from the surface of the floor to fit with the implementation of the activities then comparing all the results.

Table (1) Geometrical Considerations.

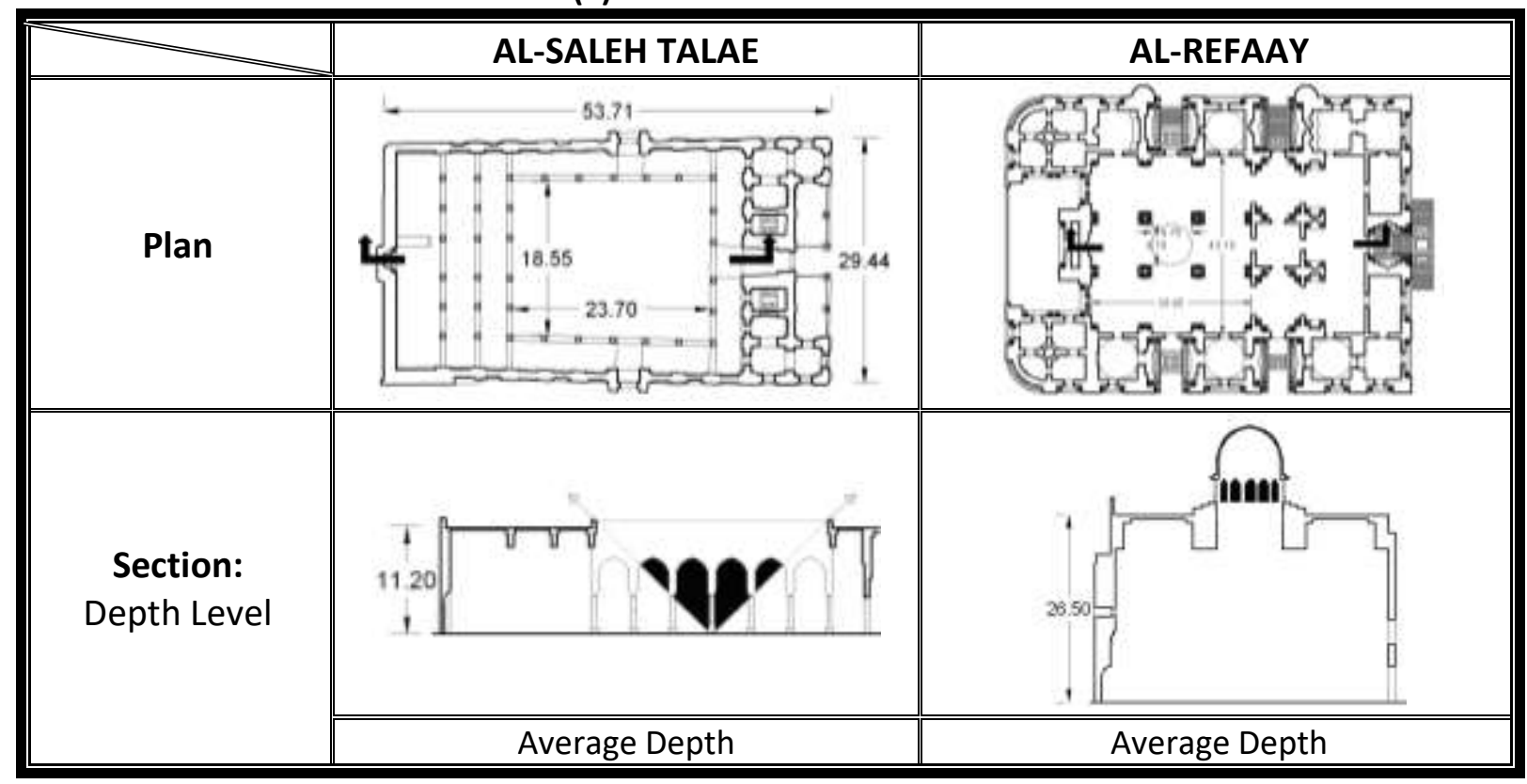

Table (2) Physical Considerations. 


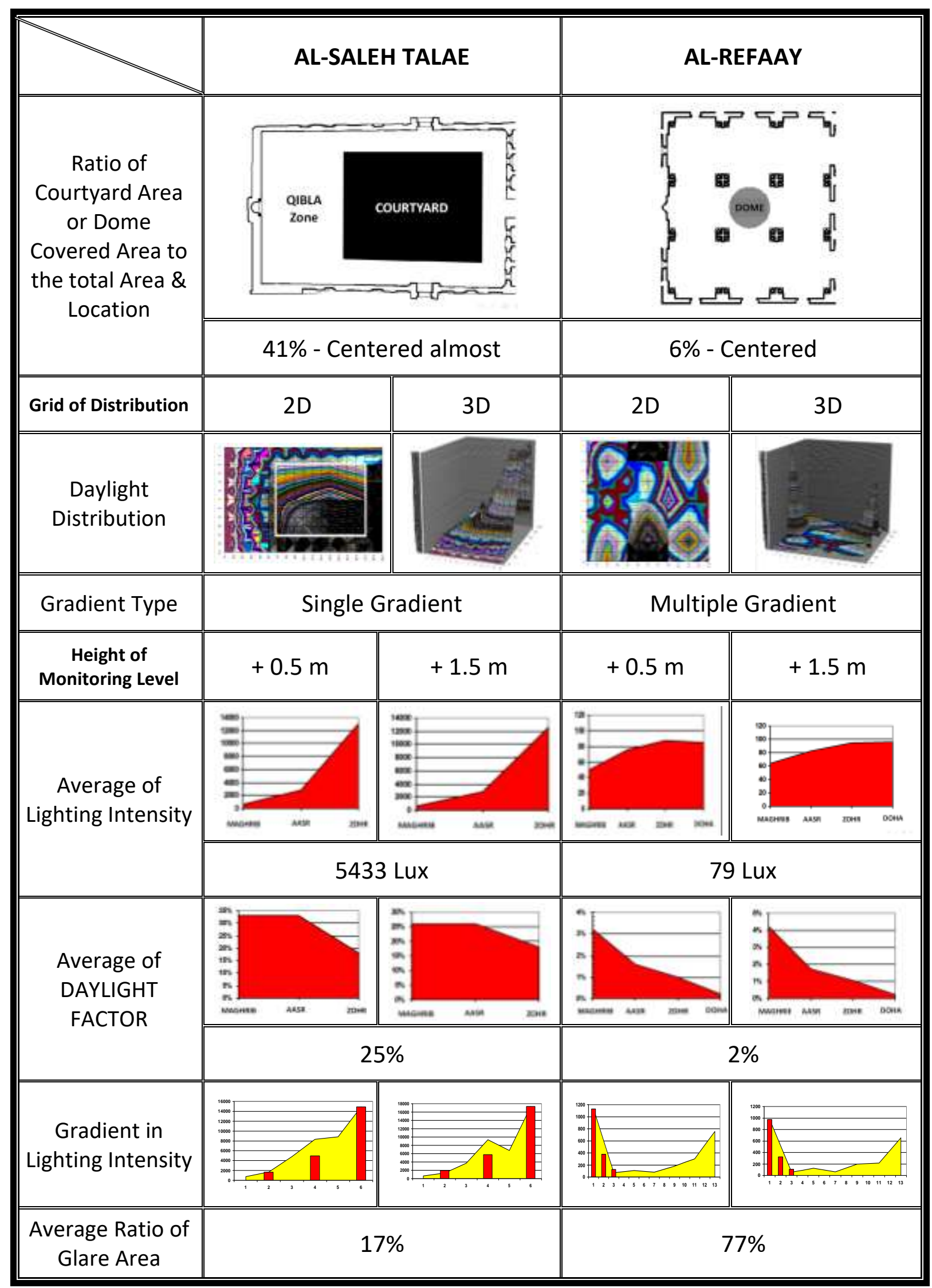

Table (3) Analytical Considerations. 


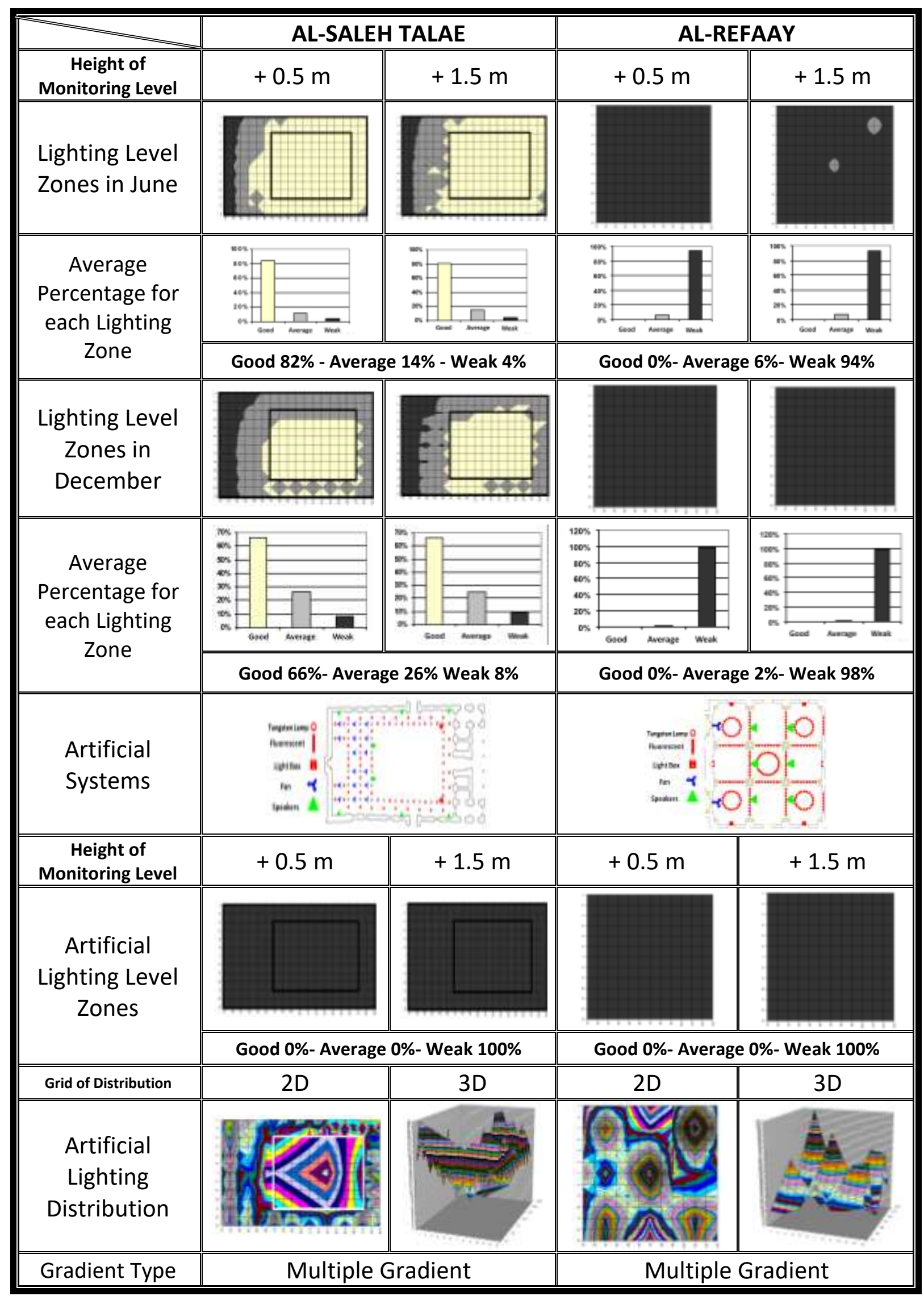




\section{Results:}

a) The average area of the internal courtyard is about $50 \%$ of the total area of MASJID ( in some early ones is about 60\% ) then decreased thereafter. In AL-ZAHRA and ALSEDDIK is about $24 \%$, while the average area which is covered by the clerestory and dome is about $13 \%$ and $11 \%$ respectively. (Fig. 12).

Fig (12) the average area of the internal courtyard / clerestory / dome of the total MASJID area.



b) The average area of vertical openings in the internal courtyard is about $73 \%$ of its facades area, and in MASJID of MOHAMED ALI and Queen SAFIA is about 36\%, while the average area of vertical openings in clerestory and dome is about $13 \%$ and $3 \%$ respectively. (Fig. 13).

Fig (13) The average area of the openings in the internal courtyard / clerestory / dome to the total area of their facades

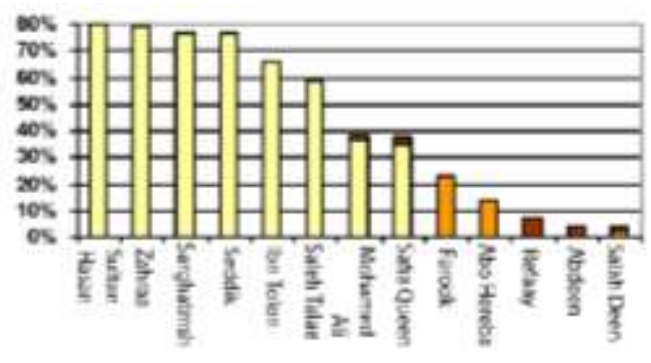

c) The average height ratio of the vertical openings in the internal courtyard is about $143 \%$ to a greatest depth of the covered area. In modern MASJID that ratio was about $32 \%$, while the average height ratio of the vertical openings in the clerestory and dome is about $19 \%$ and $26 \%$ respectively. (Fig. 14 ).

Fig (14) The average height ratio of the vertical openings in the internal courtyard / clerestory / dome to a greatest depth of the covered area.

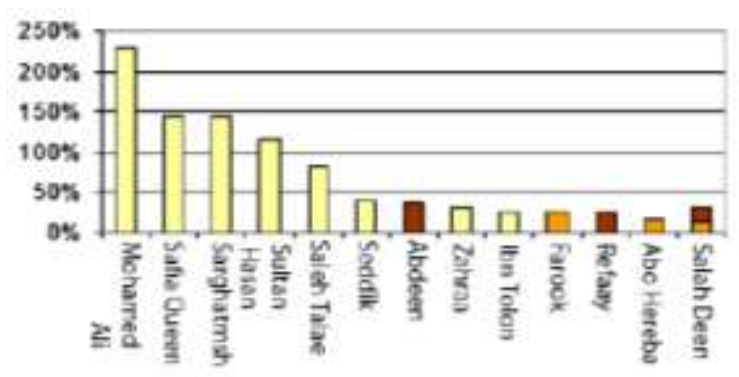

d) The average daylight intensity during the year in the covered areas of MASJID around the inner courtyard is about 6631 Ix, D.F. is $29 \%$ of external daylight. In IBN-TOLON, AL-ZAHRA and AL-SEDDIK is about 1295 IX, D.F. is 6\%. On contrary the average 
daylight intensity during the year in the covered areas of MASJID around the clerestory is about 114 Ix, D.F. is $2 \%$ and around the dome 201 Ix, D.F. is 3\%. (Fig. 15).

Fig (15) The average daylight intensity in the covered area of MAJID around the internal courtyard / clerestory / dome during the year.

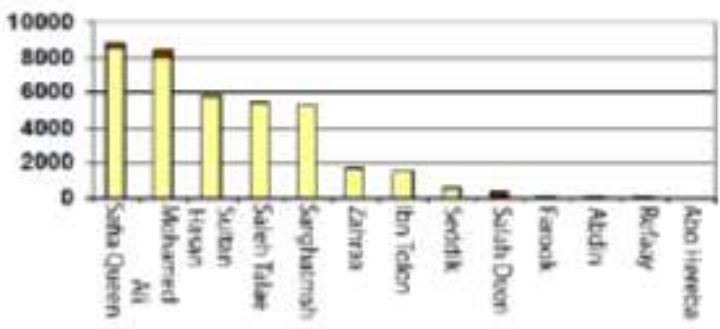

e) The average summery highly lighted area ratio (higher than $600 \mathrm{Ix}$.) in covered area around the internal courtyard is about $90 \%$ of the covered area of MASJID. In IBNTOLON, AL-ZAHRA and AL-SEDDIK is about 49\%. On contrary, the average summery highly lighted area ratio in covered area around clerestory and dome is about $1 \%$. (Fig. 16).

Fig (16) The average summery well lighted area around the internal courtyard / clerestory / dome to the total covered area of MASJID.

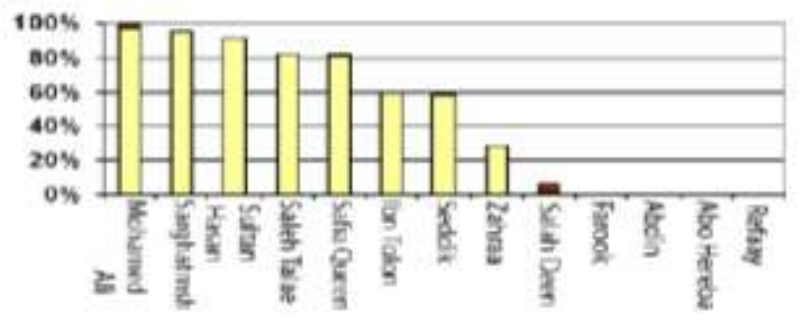

f) The average wintry highly lighted area ratio (more than $600 \mathrm{~lx}$ ) in covered area around the internal courtyard is about $71 \%$ of the covered area of MASJID. In IBNTOLON, AL-ZAHRA and AL-SEDDIK is about 33\%. On contrary, the average wintry highly lighted area ratio in covered area around clerestory and dome is about $0 \%$. (Fig. 17).

Fig (17) The average wintry well lighted area around the internal courtyard / clerestory / dome to the total covered area of MASJID.

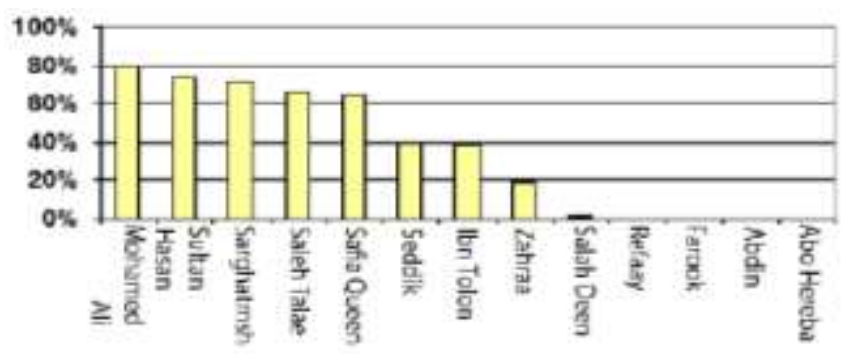

g) The average total summery electrical consumption in MASJID with internal courtyard is about $0.19 \mathrm{~W} / \mathrm{M}^{2}$.h. In AL-ZAHRAA and AL-SEDDIK, it is about $1.49 \mathrm{~W} / \mathrm{M}^{2}$.h. On contrary, the average total electrical consumption in MASJID covered by clerestory and dome is about $5.83 \mathrm{~W} / \mathrm{M}^{2} . \mathrm{h}$, and $3.31 \mathrm{~W} / \mathrm{M}^{2}$.h, respectively. In MOHAMED ALI and $A B D I N$, it is about 49.55 Watt $/ \mathrm{M}^{2}$.h. (Fig. 18). 
Fig (18) The average total summery electrical consumption in MASJID with internal courtyard / clerestory / dome.



h) The average total wintry electrical consumption in MASJID with internal courtyard is about $0.72 \mathrm{~W} / \mathrm{M}^{2}$.h. In AL-ZAHRAA and AL-SEDDIK, it is about $3.74 \mathrm{~W} / \mathrm{M}^{2}$.h. On contrary, the average total electrical consumption in MASJID covered by clerestory and dome is about $7.53 \mathrm{~W} / \mathrm{M}^{2} . \mathrm{h}$, and $4.47 \mathrm{~W} / \mathrm{M}^{2} . \mathrm{h}$, respectively. In MOHAMED ALI and ABDIN, it is about 54.18 Watt / $\mathrm{M}^{2}$.h. (Fig. 19).

Fig (19) The average total wintry electrical consumption in MASJID with internal courtyard / clerestory / dome.

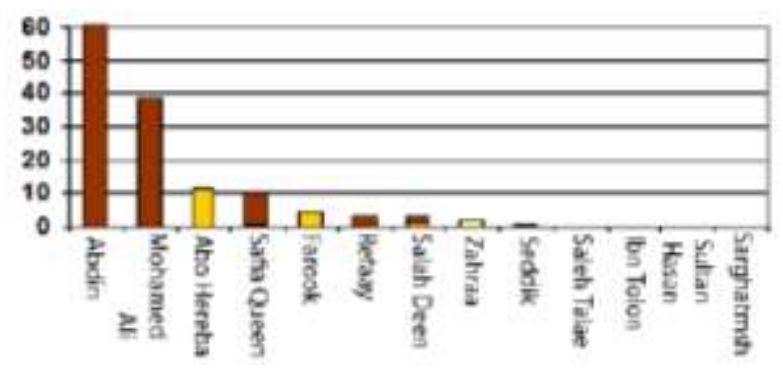

- Monitoring and analyzing the psychological and social role of internal courtyard's DAYLIGHTING in the environmental architecture of MASIID on a group of worshipers throughout a questionnaire of psychological and social impacts distributed by hand and posted on a specialized Web sites then the Excel program was used for data analysis.

\section{Discussion}

\subsection{Design parameters}

- The area of the internal courtyard is preferred to be not less than half of the total area of MASJID, and any length or width of the internal courtyard is not less than half of the overall length or width of MASJID.

- The internal courtyard is located in the center of MASJID.

- The geometry of the internal courtyard of MASJID is nearly to be a square.

- The height of the vertical openings in the internal courtyard is larger than the greatest depth of the covered area.

- The internal courtyard provides the largest area of vertical openings to the covered space inside of MASJID, and less area of vertical openings on outside.

\subsection{Physical properties:}


- The internal courtyard of MASJID provides average intensity of illumination about $6631 \mathrm{~lx}$. around the year, and D.F. of $29 \%$ of natural lighting outside.

- The average glared area from the internal courtyard is less than $2 \%$ of the area of MASIID around the year.

- The internal courtyard provides the greatest highly lighted area (higher than 600 Ix.) with an average $80 \%$ of MASJID's area around the year.

- The internal courtyard provides the least poor lighted area (less than 200 Ix.) with an average $3 \%$ of MASJID's area around the year.

- The internal courtyard reduces the consumption of electricity from the artificial lighting in MASJID for up to $0.19 \mathrm{~W} / \mathrm{M}^{2} . \mathrm{h}$ in summer, and $0.72 \mathrm{~W} / \mathrm{M}^{2}$.h in winter which is equivalent to about $4 \%$ in summer and $12 \%$ in winter of consumption in MASIID covered by clerestory or dome.

- The internal courtyard provides a difference in temperature between the inside to the outside of MASIID by factor about $95 \%$.

- The internal courtyard provides a difference in relative humidity between the inside to the outside of MASJID by factor about $96 \%$.

- The internal courtyard reduces the consumption of electricity for the ventilation in MASJID for up to $1.40 \mathrm{~W} / \mathrm{M}^{2}$.h. equivalent to about $20 \%$ of the consumption in MASJID covered by clerestory or dome.

- The internal courtyard provides a difference in noise levels between the inside to the outside of MASJID by factor about $83 \%$.

- The internal courtyard reduces the consumption of electricity for the sound systems in MASJID for up to $0.20 \mathrm{~W} / \mathrm{M}^{2}$.h. equivalent to about $20 \%$ of the consumption in MASJID covered by clerestory or dome.

\subsection{Psychological and social properties}

- The internal courtyard's DAYLIGHTING and other natural systems in MASJID supports the sense of tranquility, reverence and closeness of God ( ALLAH ), feeling of security, guidance, light, confidence and certainty.

- The natural systems including DAYLIGHTING provided by the internal courtyard are suitable to achieve psychological comfort in MASJID.

- The natural systems including DAYLIGHTING provided by the internal courtyard allow performance of different social activities in MASJID.

\section{Conclusion}

Understanding the role of the internal courtyard to provide DAYLIGHTING for the Environmental architecture of MASJID through:

\subsection{The importance of the internal courtyard's DAYLIGHTING of MASJID}

- Achieving the proper quality of lighting environment to do various activities in MASJID, and increasing the quality of the visual process, and the positive effects on human health.

- Availability to reduce the glare in MASJID.

- Avoiding the disadvantages of artificial lighting in MASJID, such as low intensity, bad distribution, and the stability of light intensity. 
- The centrality of the internal courtyard in MASJID provides strong contact to the covered spaces around it which allows using it efficiently and effectively.

- Increasing the capacity of MASJID, and supporting the possibility for different activities of worship, cultural, social and entertainment ... etc.

- Improving psychological effectiveness in MASJID, and supporting them by providing DAYLIGHTING and other natural systems.

- Allows carrying out various social activities in MASJID without the interference of those activities with each other or preventing the worshipers by providing DAYLIGHTING and other natural systems.

\subsection{The environmental impact for the internal courtyard of MASJID}

- Allow advantages of a compacted urban pattern to achieve protection from bad external climatic bad conditions, and openness to the outside world at the lowest possible space, and provide privacy.

- Providing a suitable place to contain fountains working on humidifying the air when exposed to dried hot atmosphere.

- Increase exposure to sunlight as much as possible which is necessary for thermal gain in MASJID to provide thermal comfort in winter.

- Supporting the internal air movement in MASJID that is necessary to reduce the internal temperature and get rid of over humidity.

- Renewing indoor air in MASJID to reduce viruses, various organic volatiles and air pollutants that cause the spread of diseases and epidemics.

- Allowing Efficient contact between inside space and outside of MASJID, where the advantage of opening up to the sky providing protection from external loads.

- Avoiding disadvantage of air conditioning and bad renewal of air.

- Decreasing noise between inside and outside of MASJID to achieve quietness.

- Reducing the heat island phenomenon which is created above cities due to increasing building density that cause the high temperature and relative humidity on the green areas and surrounding desert.

- Reducing noise levels in the residential area.

- Reducing the pollutants resulting from energy generation, materials manufacture, and constructions operation.

- Saving energy consumption used in the stages of manufacture of construction materials and building construction and operation.

\subsection{Development opportunities and future potentials}

- Shading the internal courtyard by smart sheeting as in the prophet's MASJID.

- Planting the green grass in the ground of internal courtyard of MASIID.

\section{Recommendations}

- Supporting the internal courtyard's DAYLIGHTING for the environmental architecture of MASJID in Cairo city. 
- Applying the design bases of the internal courtyard's DAYLIGHTING, for the advantage of its physical, psychological and social properties in the environmental architecture of MASJID.

- Studying the environmental performance of the internal courtyard's DAYLIGHTING in different activities and building kinds.

- Continuing the study of providing opportunities for the development of the internal courtyard's DAYLIGHTING in buildings.

- Continuing the evaluation of the environmental performance of the internal courtyard's GAYLIGHTING with different natural systems and studying the opportunities for its development.

\section{References}

1. AHMED ALMRAZKY, The Environmental Impact of the Internal Courtyard in the Architecture of MASJID, Master Thesis, Faculty of Engineering, Cairo University, 2010.

2. Brenister Fletcher, A History Of Architecture, Architecture Press, London, $20^{\text {th }}$ Edition, 1996, p565-573.

3. Ira G. Zepp, A Muslim Primer: Beginner's Guide to Islam, University of Arkansas Press, $2^{\text {nd }}$ Edition, 2000, p92.

4. Syed I. Ariffin, Architectural Conservation in Islam : Case Study of the Prophet's Mosque, Penerbit UTM, Malaysia, $1^{\text {st }}$ Edition, 2005, p53.

5. Doris Behrens-Abouseif, Islamic Architecture in Cairo: An Introduction, E. J. BRILL, U.S.A., 1989, p146.

6. Caroline Williams, Islamic Monuments in Cairo: The Practical Guide, American University in Cairo Press, Cairo, 6th Edition, 2008, p167.

7. Bangali Jayashri, Shaligram Arvind, Simulation of strategic placement of luminaries for energy efficient lighting using daylight, Journal of Engineering, Technology and Innovation, Vol. 2, 2013, p63.

8. R. G. Bhavani and M. A. Khan, Advanced Lighting Simulation Tools for Daylighting purpose, Trends in Applied Science Research - Vol 6 - Issu 4, 2011, p348.

9. Richard Kittler, Miroslav Kocifaj, Stanislav Darula, Daylight Science and Daylighting Technology, Springer, U.S.A., 2012.

10. Par Roger Garaudy, Mosquee, Miroir De L'Islam, Les Edition Du Tagour, 1985, p155.

11. Titus Burckhardt, Art of Islam: Language and Meaning, World Wisdom, Inc., 2009, p139.

12. David Macaulay, Mosque, Houghton Mifflin Harcourt, 2008, p11.

13. J.L. chapman \& M.J. Reiss, Ecology principles and applications, Cambridge Low Price Editions, 1995, P 3-276.

14. YEHIA ABDALLAH, Urbanism of Life and Human, Egyptian Anglo Library, Cairo, 2013, p100.

15. Robert Hillenbrand, Islamic Architecture, Edinburgh University Press, 1994, p31.

16. Karen Farrington, Historical Atlas of Religions, Checkmark Books, Thalamus Publishing, 2002, P 6.

17. Yasmine Amr Mostafa, A Framework For Building Performance Simulation Tools In A Multidisciplinary Design, M. Sc. Thesis, Faculty of Engineering, Cairo University, 2013. 


\section{الملخص}

\section{الإضاءة الطبيعية للفناء الداخلي في العمارة البيئية للمسجد بمدينة القاهرة}



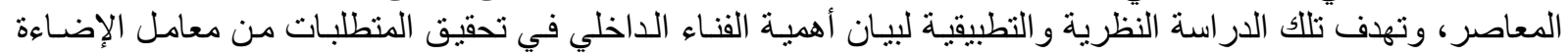

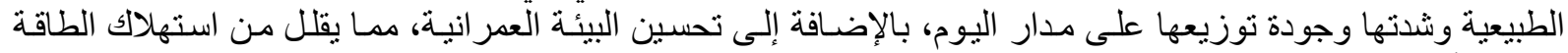
وخفض أحمال التلوث على البيئة الطبيعية.

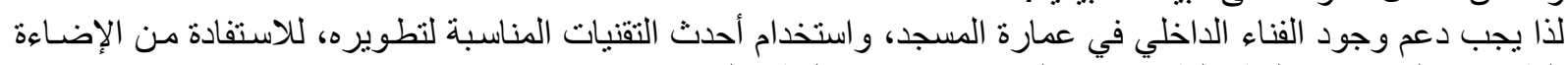
الطبيعية و المصادر و النظم الطبيعية في العمارة، ومساندة النظام البيئي. كلمات البحث: الإضـاءة، الفناء، المسجد، العمارة، البيئة، الطاقة. 